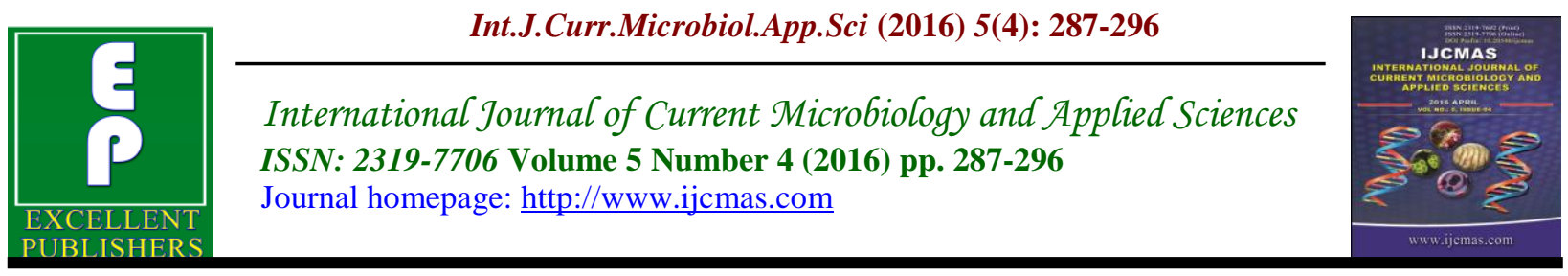

Original Research Article

http://dx.doi.org/10.20546/ijcmas.2016.504.033

\title{
Reproductive and Productive Indicators of Holstein-Friesian Cows Grown in Cubical Technology
}

\author{
Georgi Popov*, Zapryanka Shindarska and Iliya Ralchev \\ University of Forestry - Sofia, Faculty of Veterinary Medicine, Kliment Ohridski Blvd. 10 \\ *Corresponding author
}

Keywords

Production, Reproduction, Cows, Lactating Period, Sexual Cycle, Period from Calving to Fertilization.

\begin{tabular}{l}
\hline Article Info \\
\hline Accepted: \\
15 March 2016 \\
Available Online: \\
10 April 2016
\end{tabular}

\section{A B S T R A C T}

Reproductive and productive performances of Holstein - Friesian cows grown at cubic technology were studied. The study included 70 animals separated and aligned into groups according to number of lactation. The following reproductive parameters are traced: age of fertilization, age of calving, length of periods from calving to first heat and from calving to fertilization, number of inseminations, duration of pregnancy and calving period. From the productive parameters are researched: milk quantity for lactation, duration of lactation and dry period. The aim of the study is to establish productive and reproductive performances in Holstein-Friesian cows, at different lactation placed under the same technological conditions of feeding and breeding. The obtained results shows: extended duration for first, second, third and fourth lactation (respectively 347, 304, 326 and 316 days), increased number of insemination to fertilization $(1,79 ; 1,39 ; 1,71$ and 3,25 for each lactation), increased age of calving (35,5;45,8; 60,7 and 73,2 months), extended period from calving to first heat (100,1; 81,6; 64,6 and 42,7 days), from calving to fertilization $(141,6 ; 102,3 ; 126,7$ and 125,7 days $)$ and calving period $(420,7 ; 381,4 ; 405,4$ and 401,7 days $)$ for the four lactations respectively.

\section{Introduction}

Over the last ten years a number of studies on reproductive and productive performance of dairy cows are held. Results of them are too contradictory (Dematawewa 1998; Pursley et al., 1998; Lucy et al., 1998; Ajili et al., 2007; Moussavi 2008; Haworth et al., 2008 and Le Blank 2010). Some studies show impaired reproductive performances (Heinrichs and Vasquez-Anen 1993; Tozer and Hendrichs, 2001; Petraskiene et al., 2007; Gergovska 2011) which inevitably leads to reduced productivity.
Lusy et al. (1998) and Lusy (2001) specify that the decreasing level of productive efficiency in dairy farming and the reproductive state are major global problems.

Research on Dematawewa (1998), Pursley et al. (1998) and Lucy et al. (1998) in cows with the average milk of lactation 8-10 tones, indicate a prolonged period from calving to fertilization while the high milk yield is accompanied by a prolonged period 
from calving to first heat and lower levels of progesterone in the blood.

On the reproductive and productive parameters influence a number of factors. ${ }^{1}$ Penev et al. (2014) describes the effects of photoperiod on reproductive performance, and increasing milk production in healthy animals by $14.8 \%$ at a light intensity of 150 lx. Increasing the brightness of the light (respectively to 100, 150 and $200 \mathrm{~lx}$ ) leads to a shorter period from calving to fertilization with 12, 22 and 21 days.

The extended period from calving to fertilization is not always the reason for the low fertility. The reasons may be management decisions of farmers who slow insemination (Arabel et al., 2001 and Washburn et al., 2002). According to Gergovska (2009) number of lactation, respectively sequence of calving affects the duration of the period from calving to fertilization, which are respectively 185,157 and 148 days. Other authors (Washburn et al., 2002, Ajili et al., 2007 and Moussavi 2008) state extension of period from calving to fertilization with average 155 days.

Research of Le Blank (2010) shows that impact on reproductive performance has good nutrition and reproductive management. Author give evidence of high fertility in herds with average daily milk yields over 10 tons.

Rodriquez-Marinez et al., (2008) claim that raising the milkiness, the number of animals in the herd, changes in methods of breeding and insemination leads to difficulties in managing reproduction on highly productive cows.

Age at first calving is a major factor for the efficiency of dairy farms (Tozer and Heinrichs, 2001), which leads to realization of the genetic potential (Nilforooshan and Edriss 2004). In a study of Gergovska (2011) is established average age of first calving - 30 months, which is high and inconsistent with the recommended - 24 months. According to other authors (Petraskiene et al., 2007) conducted research in Latvia the average age of first calving is between 24-29 months. Pirlo et al., (2000) establish average age 28 months to a study in Italy, Perez et al. (1999) for Spain - 28.6 months, Hare et al. (2006) for USA - 27 months and Nilforooshan and Edriss (2004) for Iran - 27 months. Tozer and Heinrichs (2001) recommended average age of first calving 24 months with weight of the animal $560 \mathrm{~kg}$. In countries like Netherlands there is a tendency for insemination of dairy heifers before 15 months of age (Mourits et al., 2000), and the factors on physiological development is not taken into account. Other authors (Haworth et al., 2008) give optimal age of first calving in Australia - 2.5 years (30 months), noting that these animals have high milk yield of first lactation and prolonged period of economic use. Gaidarska et al. (2008) does indicate age of first calving 25 months, while cows at that age have a long period of economic use and lifetime milk yield. These findings are confirmed by other authors (Tozar and Heinrichs, 2001). With increasing the age Gaidarska et al., (2008) establishes deterioration of reproductive and productive performance. Impacts on age at first calving have breed, age of puberty, management, nutrition and weight (Krustev 2002 and Rusev et al., 2001). Krustev et al., (2002) recommended in Bulgaria age of first calving at 28 months for milk breeds with a strong genetic potential for high milk yield.

Research of (Veerkamp et al., 2000) shows negative correlation between milk production and recovery of luteal activity. Negative correlation between milk 
productivity and expression of estrus is described by Cutullic et al. (2009) and milk productivity and period from calving to fertilization by Abdallah and McDaniel (2000) and Haile-Mariam et al. (2003).

At age less than 24 months of first calving the calving period in cows from Holstein Friesian breed is extended and for optimal age they considered 25-26 months (Evans et al., 2006). In second and third calving authors recommend optimal calving period 37-38 months and 49-50 months respectively. Penev et al. (2014) recommended optimal age for fertilization 15-18 months and calving from 24.5 to 27.5 months respectively.

Krpálková et al. (2014) establish duration of calving period 396 days with 105 days period from calving to fertilization and age at first calving 25 months. According to the authors highest milk yield $(8500 \mathrm{~kg})$ is attained at the age of first calving of 26 months, they found that increased milkiness results in impaired fecundity.

Penev et al. (2014), Penev et al. (2014), Penev et al. (2013) and Dospatliev et al. (2015) said that mastitis and ungulate diseases are factors affecting milk production.

Ugur and Akbulut (2005) recommended duration of dry period for cows 40-50 days without negative effect on milk production. Todorov (2005) recommended average length of the dry period 60 days and allow variation within $45-70$ days, with a view to developing maximum milk yield for lactation.

From the literature finds that emerged we see that the factors influencing reproductive and productive indicators are many. Recommendations which are made and exported and the results of them are contradictory. This gave us reason of this study to analyze information on some reproductive and productive parameters in a farm for dairy cows.

\section{Materials and Methods}

A study with 70 dairy cows of the HolsteinFriesian breed on a farm in South-East region of Bulgaria was held. The animals were grouped according to number of lactation in four groups. The scheme of the experiment is presented in (Table 1). It is seen that the number of cows on 1, 2, 3 and 4 completed lactations is respectively 29,23 , 14 and 4.

Table.1 Scheme of the Experiment

\begin{tabular}{|c|c|c|c|c|}
\hline Groups & $\begin{array}{c}\mathbf{1} \\
\text { First } \\
\text { lactation }\end{array}$ & $\begin{array}{c}\mathbf{2} \\
\text { Second } \\
\text { lactation }\end{array}$ & $\begin{array}{c}\mathbf{3} \\
\text { Third } \\
\text { lactation }\end{array}$ & $\begin{array}{c}\mathbf{4} \\
\text { Fourth } \\
\text { lactation }\end{array}$ \\
\hline $\begin{array}{c}\text { Number of } \\
\text { animals }\end{array}$ & 29 & 23 & 14 & 4 \\
\hline
\end{tabular}

The growing of livestock is cubical with separate beds for relaxation. The area for feeding and drinking is consistent with welfare requirements (Regulation № 16 of February 3, 2006 issued by the "Ministry of Agriculture and Forestry" Bulgaria). Nutrition is consistent with milkiness and the reproductive status of the animals.

On Table 2 is given a daily ration of dairy cows over 301 milk yield. From it is seen that the basic ration include: hay, straw, corn silage, corn and wheat. The compound feed includes: beer mash $(7 \mathrm{~kg})$, sunflower groats $(3.5 \mathrm{~kg})$, rapeseed groats $(1.4 \mathrm{~kg})$ and chalk $(0.15 \mathrm{~kg})$.

During the study were followed these reproductive performances: age of fertilization, age of calving, length of periods from calving to first heat and from calving to fertilization, number of inseminations, duration of pregnancy and calving period. Also the following 
productive parameters are studied: milk quantity for lactation, duration of lactation and dry period. Animal health, the amount of food and reproductive status are controlled daily and milkiness for the whole period of lactation.

Statistical processing is carried out with Excel of Microsoft Office Professional plus 2010 and Graphpad Software.

\section{Results and Discussion}

The survey results are presented in Table 3 and 4. Data show that the age of fertilization of cows grows proportionally with number of lactation and for cows finished first, second, third and fourth lactation they are respectively 26.2, 36.8, 51.7 and 64.2 months. The age of calving follows the trends observed in the age of fertilization (for each lactations they are respectively 35.5, 45.8, 60.7 and 73.2 months). Our results are higher than those set by others (Evans et al., 2006, Hare et al., 2006, Gaidarska et al., 2008, Petraskiene et al., 2007 and Gergovska 2011), which gives age at first calving in range 24-29 months.

The received data about the duration of the period from calving to first heat shows short length in fourth lactation (fourth group 42.7 days), while the duration of first lactation is longest (100.1 days).

An important indicator of reproduction is the duration of the period from calving to fertilization. Data show that in the first group (141,6 days) the variation of the indicator is with the highest values $(71,8$ days). For the rest consecutive lactations (2 and 3 group) the duration of this period ranges respectively 102,3 and 126,7 days with less variation respectively 65.9 and 56.3 days. The fourth consecutive lactation have duration 125.7 days with SD - 39,1 days. Gergovska (2009) indicates a longer period from calving to fertilization established by us for first, second and third lactation (respectively - 185, 157 and 148 days), and other authors (Washburn et al., 2002, Ajili et al., 2007 and Moussavi 2008) who give average duration of that period 155 days.

In fourth lactation fertilization has taken place with the largest number of insemination (3.25), followed by consecutive first lactation (1.79), third consecutive lactation (1.71) and the second consecutive lactation (1.39).

Table.2 Average Daily Ration of Cows in Lactation

\begin{tabular}{|c|c|c|c|c|c|c|c|}
\hline Type of fodders & Kg & $\begin{array}{c}\text { DM, } \\
\text { kg }\end{array}$ & $\begin{array}{c}\text { E, } \\
\text { KEM } \\
\end{array}$ & $\begin{array}{c}\mathbf{C P}, \\
\mathrm{g}\end{array}$ & $\begin{array}{c}\text { BPR, } \\
\mathbf{g} \\
\end{array}$ & $\begin{array}{c}\text { Ca, } \\
\text { g } \\
\end{array}$ & $\begin{array}{c}\mathbf{P} \\
\mathbf{g}\end{array}$ \\
\hline \multicolumn{8}{|l|}{ Basic ration } \\
\hline Hay & 2 & 1,74 & 1,46 & 228 & 26 & 12,00 & 4,88 \\
\hline Straw & 1 & 0,87 & 0,48 & 31 & -45 & 3,05 & 0,70 \\
\hline Corn silage & 18 & 5,4 & 5,58 & 468 & -144 & 20,52 & 11,7 \\
\hline Corn & 3,5 & 4 & 4,73 & 311,5 & -126 & 0,91 & 9,73 \\
\hline Wheat & 1,5 & 1,3 & 1,89 & 193,5 & $-25,5$ & 0,78 & 5,48 \\
\hline Combined feed $*$ & 12.05 & 11,9 & 10,63 & 3075,8 & 865.9 & 91,37 & 90,3 \\
\hline Total: & 38,05 & 25,21 & 24,77 & 4307,8 & 551,4 & 128,63 & 122,79 \\
\hline
\end{tabular}


Table.3 Reproductive Indicators

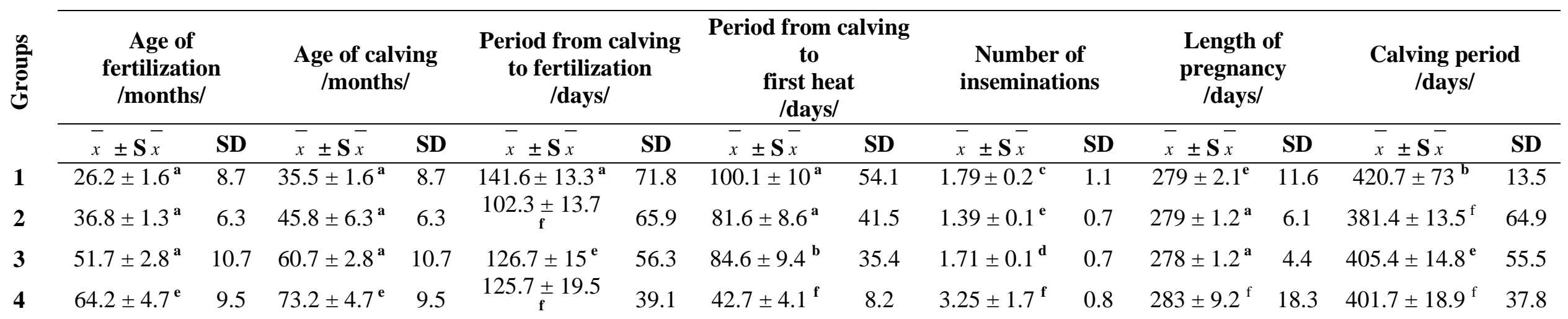

SD - Standard Deviation, $\mathbf{a}$ - significant at $\mathrm{P} \leq 0.0001, \mathbf{b}$ - significant at $\mathrm{P} \leq 0.0005, \mathbf{c}$ - significant at $\mathrm{P} \leq 0.001, \mathbf{d}-$ significant at $\mathrm{P} \leq 0.005, \mathbf{e}-$ significant at $\mathrm{P} \leq 0.05, \mathbf{f}-$ insignificant at $\mathrm{P} \geq 0.1$

Table.4 Productive Indicators

Indicators

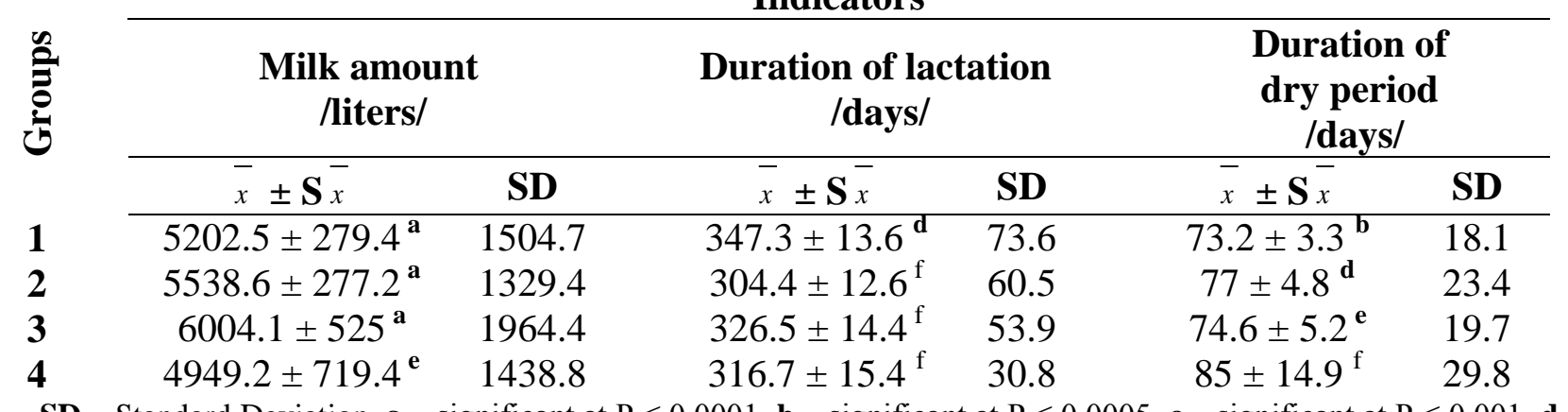

SD - Standard Deviation, $\mathbf{a}$ - significant at $\mathrm{P} \leq 0.0001, \mathbf{b}$ - significant at $\mathrm{P} \leq 0.0005, \mathbf{c}$ - significant at $\mathrm{P} \leq 0.001, \mathbf{d}$ - significant at $\mathrm{P} \leq$ $0.005, \mathbf{e}-$ significant at $\mathrm{P} \leq 0.05, \mathbf{f}-$ insignificant at $\mathrm{P} \geq 0.1$ 
Figure.1 Coefficient of Variation of Reproductive Indicators - V - \%

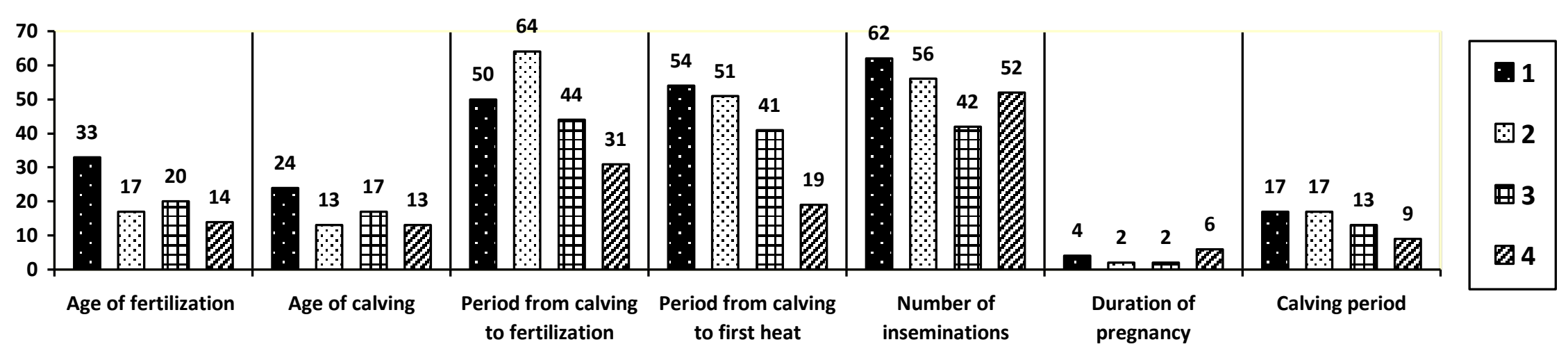

Figure.2 Coefficient of Variation of Productive Indicators - V - \%

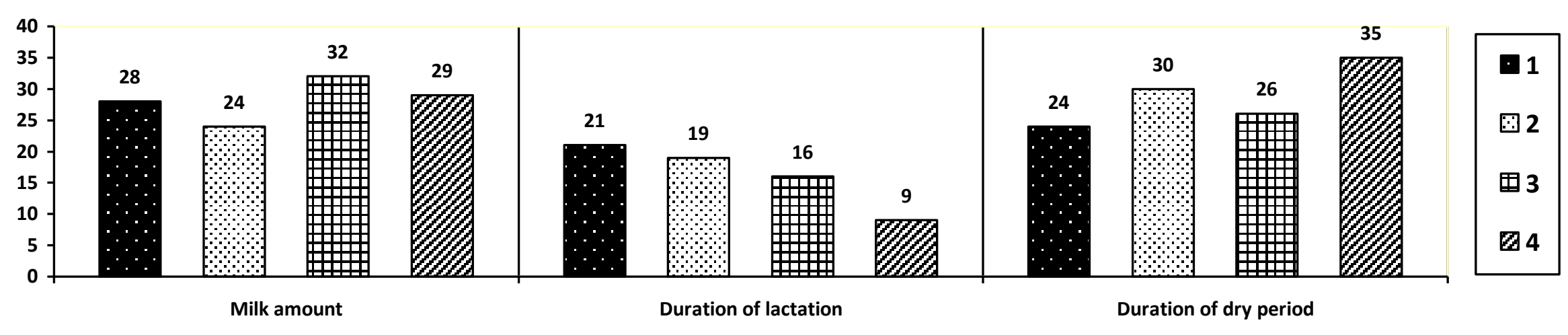


In optimal duration of pregnancy (285 days) the tested animals of first and second group have 279 days. In third consecutive lactation duration of pregnancy is 278 days and for the fourth - 283 days.

It is noteworthy that in our study the calving period is over optimal indicated in the literature. Data show also variation in the length of calving period for all groups. The longest period was in the first lactation 420, 7 days and shortest in a second group 381 days. In similar studies of our other authors (Krpálková et al., 2014) found 396 days calving period at 105 days period from calving to fertilization and 25 months of age at first calving. In our case, the longer duration of the calving period is due to the extension of the period from calving to first heat, the period from calving to fertilization and the higher age at first calving (35.5 months). The results of our study show that the values of study reproductive indicators are close to or above the norms described as optimal in the literature.

On Table 4 are shown some productivity indicators, such as milk from complete lactation duration of lactation and dry period.

Regarding the indicator total milk for lactating cow is seen that the highest in the group of cows is third consecutive lactation, followed by the second and first lactation. It is noteworthy that with the order of lactation is increased the amount of milk (from 5.2 tons of first lactation to 6 tons on third lactation). An exception is the fourth lactation where the total amount of milk is lowest (4949.2 1). One of the reasons may be a small number of animals included in the group. Variation about indicator milkiness for all groups is from 1.3 to 1.9 tons.

Regarding the index duration of lactation in our study it is longer than the optimal shown in the literature. The rate was respectively $347.3,304.4,326.5$ and 316.7 days.

The length of the dry period is almost the same for all subsequent lactations, with minor differences. Common to all animals the length of the dry period is in the range of 73.2 to 85 days with a slight variation for the different consecutive lactations. The duration of the dry period is over the optimum indicated by Todorov (2005).

The results for productive and productive indicators have different degree and level of probability ranging from significant at $\mathrm{P} \leq$ 0.0001 to insignificant at $\mathrm{P} \geq 0.1$. For first, second and third lactation data were statistically significant, while those for fourth lactation are insignificant. This is most likely due to the small number of animals in the group. Figure 1 and 2 presents the coefficients of variation of reproductive and productive indicators in percentage.

The coefficient of variation about indicators age of fertilization and calving are respectively in range $14-33 \%$ and $13-24 \%$. The coefficients are highest in the first group.

Regarding the duration of the periods from calving to fertilization and from calving to first heat variations are within the range respectively $19-54 \%$ and 31-64 \%. The variations in the period from calving to first heat are most pronounced in the first group, and for the period from calving to fertilization in the second group.

Regarding number of insemination the rate for the first group is highest $(62 \%)$. From all reproductive parameters the duration of pregnancy is with almost no variation (between 2 and $6 \%$ in the groups). 
Variation in the length of calving period is most pronounced in the first and second consecutive lactation (17\%). A coefficient of variation of the indicator milk for lactation shows most variation in third lactation (32 \%) and least for second lactation (24\%). The length of the dry period varies at lowest level $(24 \%)$ in first lactation.

In conclusion, the results showed higher reproductive parameters than those described in the literature. The most pronounced are the indicators age of fertilization and age of calving.

Extension of reproductive periods leads to an extension of the lactation period, regardless of the number of lactation.

Relationships between reproductive and productive indicators have been established and show affection of the economic efficiency of the farm.

\section{References}

Abdallah, J.M., McDaniel, B.T. 2000. Genetic parameters and trends of milk, fat, days open, and body weight after calving in North Carolina experimental herds. J. Dairy Sci., 83: 1364-1370.

Ajili, N., Rwkik, B., Ben Gara, A., Bouraoui, R. 2007. Relationships among milk production, reproductive traits and herd life for Tunisian Holstein-Friesian cows. African $J$. Agri. Res., 2: 47-51.

Arabel, R., Bigun, Y., Ezra, E., Sturman, H., Hojman, D. 2001. The effect of extended calving intervals in high lactating cows on milk production and profitability. J. Dairy Sci., 84: 600608.
Cutullic, E., Delaby, L., Causeur, D., Michel, G., Disenhaus, C. 2009. Hierarchy of factors affecting behavioural signs used for oestrus detection of Holstein and Normande dairy cows in a seasonal calving system. Anim. Reprod. Sci., 113: 2237.

Dematawewa, C.M., Berger, P.J. 1998. Genetic and phenotypic parameters for 305-day yield, fertility and survival in Holsteins. J. Dairy Sci., 81: 27002709.

Dospatliev Lilko, Alexander Aatanasoff, Gergana Kostadinova, Toncho Penev, Tchonka Miteva, Veselin Kirov. 2015. Factors associated with change in ph, ammonia and total nitrogen of manure mass in high performance dairy cows. Vet. Med. Zoot. T., 70(92): 10-15.

Evans, R.D., Wallace, M., Garrick, D.D., Dillon, P., Berry, D.P., Olori, V. 2006. Effects of calving age, breed fraction and month of calving on calving interval and survival across parities in Irish spring-calving dairy cows. Livestock Sci., 100: 216-230.

Gaidarska, V., Popova, I., Laleva, S. 2008. Study of the duration of the economic use of cows from Black and white breed. Ani. Sci., XLV(4): 9-12.

Gergovska, Zh. 2009. Factors affecting duration of the days open and its relation to productive traits in Blackand-White cows. Agri. Sci. Technol., 1(2): 1-6.

Gergovska, Zh. 2011. Effect of the age at first calving on the test day production traits in black-and-white cows. Agri. Sci. Technol., 3(2): 67-72.

Haile-Mariam, M., Bowman, P.J., Goddard, M.E. 2003. Genetic and environmental relationship among calving interval, survival, persistency of milk yield and somatic cell count in dairy cattle. Livest. Prod. Sci., 80: 189-200. 
Hare, E., Norman, H., Wright, J. 2006. Trends in calving ages and calving intervals for dairy cattle breeds in United States. J. Dairy Sci., 89: 365370.

Haworth, G., Tranter, W., Chuck, J., Wathes, D. 2008. Relationships between age at first calving and first lactation milk yield, and lifetime productivity and longevity in dairy cows. The Vet. Record, 162: 643-647.

Heinrichs, A., Vasquez-Anon, M. 1993. Changes in first lactation dairy herd improvement records. J. Dairy Sci., 76: 671-675.

Krpálková, L., Cabrera, V.E., Kvapilík, J., Burdych, J., Crump, P. 2014. Associations between age at first calving, rearing average daily weight gain, herd milk yield and dairy herd production, reproduction, and profitability. J. Dairy Sci., Volume 97, Issue 10, 6573-6582.

Krustev, M., Gaidarska, V., Tateva, M. 2002. Influence of some factors on productive longevity of cows from Black and white breed. II. Age and body weight at first mating, respectively calving. Ani. Sci., 39(6): 7-8.

LeBlanc, S. 2010. Assessing the association of the level of milk production with reproductive performance in dairy cattle. J. Reprod. Dev., 56 Suppl., S1S7.

Losinger, W.C., Heinrichs, A.J. 1996. Dairy operation management practices and herd milk production. J. Dairy Sci., 79: 506-514.

Lusy, M.C. 2001. Reproductive loss in highproducing dairy cattle: Where will it end. J. Dairy Sci., 84: 1277-1293.

Lusy, M.C., Weber, W.G., Baumherd, L.H., Seguin, B.S., Koenigsfield, A.T., Hansen, L.B., Chester-Jones, H., Crooker, B.A. 1998. Reproductive endocrinology of lactating dairy cows selected for increased milk production. J. Animal Sci., 73: 296.

Mourits, M., Van der Fels-Klerx, H., Huirne, R., Huyben, M. 2000. Dairyheifer management in the Netherlands. Preventive Vet. Med., 46: 197-208.

Moussavi, A. 2008. Influences of milk yield and fertility traits in the first lactation on the length of productive life of Holstein dairy cows in Iran. Res. J. Biol. Sci., 3: 1022-1027.

Nilforooshan, M., Edriss, M. 2004. Effect of age at first calving on same productive and longevity traits in Iranian Holsteins of the Isfahan Province. $J$. Dairy Sci., 87: 2130-2135.

Petraskiene, R., Girskiena, B., Paleckaitis, M. 2007. Influence of age at first calving on production traits in Lithuanian black-and-white cattle population. Veterinarija ir Zootechnika, 40: 62.

Penev, T., Vasilev, N., Stankov, K., Mitev, J., Kirov, V. 2014. Impact of heifers age at first breeding and first calving on some parameters of economic effectiveness at dairy cattle farms. Int. J. Curr. Microbiol. App. Sci., 3(11): 772-778.

Penev Toncho, Veselin Radev, Todor Slavov, Veselin Kirov, Dimo Dimov, Alexandar Atanassov, Ivaylo Marinov. 2014. Effect of lighting on the growth, development, behaviour, production and reproduction traits in dairy cows. Int. J. Curr. Microbiol. App. Sci., 3(11): 798-810.

Penev, T., Gergovska, Zh., Marinov, I., Kirov, V., Stankov, K., Mitev, Y., Miteva, Ch. 2014. Effect of season, lactation period and number of lactation on mastitis incidence and milk yields in dairy cows. Agri. Sci. Technol., 6(2): 231-238. 
Penev, T., Manolov, Z., Dimov, D., Kirov, V., Uzunova, K., Dimova, V., Radev, V. 2014. Investigation of some hoof disease prevention practices on claw horn hardness and frictional properties in dairy cattle. Ani. Studies Vet. Med., Volume 4, Number 1, 63-73.

Penev, T., Manolov, Z., Borissov, I., Dimova, V., Miteva, Tch., Mitev, Y., Kirov, V. 2013. Investigations on friction coefficients of cow hooves with different dairy farm floor types. Agri. Sci. Technol., Vol. 5, No 3, pp. 305-308.

Perez, M., Hernandez, D., Alenda, R., Carabano, M., Charfeddine, N. 1999. Genetic analysis of true profit for Spanish dairy cattle. https://journal.interbull.org/

Pirlo, G., Miglior, F., Speroni, M. 2000. Effect of age at first calving on production traits and on difference between milk yield returns andrearing costs in Italian Holsteins. J. Dairy Sci., 83: 603-608.

Pursley, J.R., Silicox, R.W., Wiltbank, M.C. 1998. Effect of time of artificial insemination on pregnancy rates, calving rates, pregnancy loss, and gender ratio after synchronization of ovulation in lactating dairy cows. $J$. Dairy Sci., 81: 2139-2144.

Rodriguez-Martinez, H., Hultgren, J., Bage, R., Bergqvist, A.-S., Svensson, C., Bergsten, C., Lidfors, L., Gunnarsson,
S., Algers, B., Emanuelson, U., Berglund, B., Andersson, G., Haard, M., Lindhe, B., Stalhammar, H., Gustafsson, H. (Eds.) 2008. Reproductive Performance in Highproducing Dairy Cows: Can We Sustain it Under Current Practice, International Veterinary Information Service, Ithaca, NY.

Rusev, N., Gorinov, Q., Lidji, K., Gaidarska, V. 2001. Study trends in dairy farming at worldwide and in our country. Ani. Sci., XXXVIII, 1: 22-28.

Todorov, N. 2005. How should last dry period in cows, Livestock Plus, 2: 5-7.

Tozer, P., Heinrichs, A. 2001. What affects the costs of raising replacement dairy heifers: A multiple-component analysis. J. Dairy Sci., 84: 1836-1844.

Ugur, F., Akbulut, M.D. 2005. Effect of dry period length on milk yield traits of Holstein Friesian cattle. Bulgarian J. Agri. Sci., 11: 189-191.

Veerkamp, R.F., Oldenbroek, J.K., Van der Gaast, H.J., Van der Werf, J.H. 2000. Genetic correlation between days until start of luteal activity and milk yield, energy balance, and live weights. $J$. Dairy Sci., 83: 577-583.

Washburn, S., Silva, W., Brown, C., McDaniel, B., McAllister, A. 2002. Trends in reproductive performance in Southeastern Holstein and Jersey DHI herds. J. Dairy Sci., 85: 244-251.

How to cite this article:

Georgi Popov, Zapryanka Shindarska and Iliya Ralchev. 2016. Reproductive and Productive Indicators of Holstein-Friesian Cows Grown in Cubical Technology. Int.J.Curr.Microbiol.App.Sci. 5(4): 287-296. doi: http://dx.doi.org/10.20546/ijcmas.2016.504.033 